\title{
The Effect of Insect Repellent Exposure on Leukocyte Profile and Histopathologic Findings in Lungs
}

\author{
Ary Andini 1,*(D), Marwatul Hasanah 1, Shinta Nuryah Azizah', Asma Rubiah Rosyadahan 1, Defi \\ Rimasari ${ }^{1}$, Widita Triapadma ${ }^{1}$, Friska Ayu ${ }^{2}$ (D), Achmad Syafiuddin 3 (D) \\ 1 Department of Medical Technology Laboratory, Universitas Nahdlatul Ulama Surabaya, J1. Jemursari No. 51-57 Surabaya, \\ East Java, Indonesia \\ 2 Department of Occupational Health and Safety, Universitas Nahdlatul Ulama Surabaya, Jl. Jemursari No. 51-57 Surabaya, \\ East Java, Indonesia \\ 3 Department of Public Health, Universitas Nahdlatul Ulama Surabaya, J1. Jemursari No. 51-57 Surabaya, East Java, \\ Indonesia \\ * Correspondence: aryandini@unusa.ac.id (A.A.);
}

Received: 22.09.2021; Revised: 29.10.2021; Accepted: 3.11.2021; Published: 1.12.2021

\begin{abstract}
Organophosphate compounds in insect repellent have a role in contributing to mosquito mortality but have toxic effects for humans when exposed for a long time. The research is aimed to analyze the effect of insect repellent exposure in blood leukocyte profile and histopathologic findings in lungs. The study used thirty males Rattus novergicus, which were divided into three groups, such as electric liquid insect repellent (P1) with contain $0.031 \%$ dimefluthrin, anti-mosquito coils (P2) with $0.014 \%$ dimefluthrin, and electric mat mosquito repellent with $0.566 \%$ dimefluthrin for 8 hours in 20 days respectively. Leukocyte profiles were determined by using the blood smear method, and the lung's health was identified by histopathologic findings. Based on the results study showed mosquito coils exposure increase the lymphocytes count. Meanwhile, the electric liquid-repellent increased the basophil's numbers. The electric mat exposure had more eosinophils, neutrophils stab, neutrophils segment, and monocytes in the blood. The leukocyte profile of each group showed there were no statistically significant differences (P-value > 0.05). Based on histopathology, lung findings showed that the electric mat exposure contributed to cells degeneration $7.5 \%$ and pleural thickening $30 \%$. The higher dimefluthrin concentrations in insect repellents could affect leukocyte profile and lungs health.
\end{abstract}

Keywords: mosquito; repellent; leukocyte; lungs.

(C) 2021 by the authors. This article is an open-access article distributed under the terms and conditions of the Creative Commons Attribution (CC BY) license (https://creativecommons.org/licenses/by/4.0/).

\section{Introduction}

The mosquitos are decreased, followed by wind and higher temperature, but at the end of warm weather, mosquitoes consistently increase in numbers [1]. In Indonesia, the transitional season from dry to rainy or otherwise promotes the breed of mosquitos that could interfere with human comfort. Insect repellent is used to inhibit mosquitos' action, but no one knows the effect on health for long-term use. In addition, active substances in insect repellent contain organophosphates that harm human health; they could have hazardous interactions with the biological system in the body [2]. Therefore, insect repellent must be used properly according to the type and doses of insect repellent.

Based on Chang and Lin (1998) study explained that insect repellant coils produced smoke which contains small particles with a size of 1 micrometer, metal fumes, vapors, and free radicals[3] when the smoker each the alveoli of the lungs could cause irritation in the upper 
respiratory tract and produce large amounts of sub-micrometer particles. Whereas when the smoke reaches the lower respiratory tract, it could contribute to carcinogenesis [3]. The smoke of insect repellent coils is toxic pollution that has been reported to have adverse effects on the environment and human health $[4,5]$.

Other innovations of mosquito repellent are liquid electric and mat electric. Both insect repellent electric does not produce smoke like mosquito coils. The electric mosquito-repellent liquid, which contains prallethrin $1.6 \%$ insecticides, might cause hematological toxicity, and the pyrethroid group in liquid insect repellent leads to biochemical, hematological, neurological changes cytokine disturbance, and mutagenic damage in tissues [6,7]. Not only could it contribute to pollutants in the air [8], but also the active substance in both electric insect repellent is leading to biotransformation and followed by bioaccumulation that might have a toxic response in the body [2].

Most ingredients used for insect repellents contain DEET, IR3535 (Ethyl Butylacetylaminopropionate) (EB), Icaridin (Picaridin), and pyrethroids which present advantages and disadvantages [9-11]. Dimefluthrin is one of the active ingredients belonging to pyrethroids that can control dengue vectors [12]. It has an excellent knockdown activity for insects [13]. Improper combustion of insect repellent containing dimefluthrin produces harmful gases to the human body if used for a long time [14].

The aerosol and smoke of mosquito repellent usage contribute to pollution in ambient air that could disrupt the respiratory system and organ function. Interaction of free radicals from mosquito repellent exposure could affect leukocyte profile in blood and lungs disruption organ [15]. Histopathological studies of deltamethrin and other insect repellents exposure in rats could cause lung toxicity $[15,16]$. Besides, the D-Allethrin content in insect repellent affected the liver, kidney, teratogenic effects in fetuses and led to respiratory problems by irritating the trachea [16-18]. The study was focused on analyzing the effect of exposure to insect repellent in various types such as electric liquid insect repellent, anti-mosquito coils, and electric mat insect repellent, which contain various dimefluthrin concentrations toward the differential count of leukocytes in the blood and histopathologic findings in lungs.

\section{Materials and Methods}

The study was in vivo experiment research with a cross-sectional approach. The research used 30 male Rattus novergicus strain Wistar weighing 150-250 gr. The mice were divided into 3 groups, including 10 mice subjected to insect repellent liquid electric exposure (P1), 10 mice subjected to insect repellent coils exposure (P2), and 10 mice subjected to insect repellent mat electric exposure (P3). The length of exposure was conducted for 8 hours a day in 20 days each. The research has approved ethical clearance through No. 062/EC/KEPK/UNUSA/2021.

The intervention activity used an exposure of mosquito coils (P1) with dimefluthrin content of about $0.031 \%$, mosquito liquid electric (P2) with dimefluthrin content about $0.014 \%$, and mosquito mat electric (P3) with dimefluthrin content about $0.566 \%$ on mice for 8 hours a day in 20 days respectively. A set of surgical instruments, ketamine (Ket-A-100) for anesthesia, and pot samples for saving the lungs in fixative solutions such as buffer formalin $10 \%$. The blood smear test uses Giemsa for staining [8]. The histopathological slide used several pieces of equipment that consists of microtome Thermo Scientific, object-glass, cover glass, label paper, microscope Olympus CX-22 for observing the cells necrosis, cell degeneration, pleural 
thickening, and leukocyte profile through blood smear test, a set of hematoxylin-eosin (HE) for staining, alcohol, xylene and paraffin Diapath for histotechnique processing.

\subsection{Differential count of leukocyte.}

Differential count of leukocytes was observed using blood smear methods. The leukocyte profile consists of basophile, eosinophil, neutrophil stab, neutrophil segments, lymphocyte, monocyte. The procedure was carried out by one drop of blood put on the objectglass, then covered by another object glass and smeared at an angle of $30-40^{\circ}$ and dried for 5 minutes $[19,20]$. Furthermore, the specimens were dived in a fixative solution for 2-3 minutes, then dripped the Giemsa dye on the specimen $[19,20]$. Leukocyte profiles including basophils, lymphocytes, neutrophils stab, neutrophils segments, monocytes, eosinophils were observed using a microscope Olympus CX-22 with a magnification of 1000x [20].

\subsection{Histopathological.}

The lungs organ of rats was collected on the 20th day or the end of intervention activity then preserved in buffer formalin solution $10 \%$ for further steps, including trimming, processing of lung tissue, embedding, slicing by using a microtome, staining by HematoxylinEosin (HE), and observing under a microscope [21] with magnitude 4000X.

\subsection{Data analysis.}

The differential count of leukocytes including basophils, eosinophils, neutrophils stab and segments, lymphocyte, monocyte. The leukocytes profile data were analyzed using the Anova One Way test for parametric data and the Kruskal Wallis test for non-parametric data. The histopathologic findings in the lungs were identified by observing necrosis, cells degeneration, and pleural thickening based on the score of interpretation data seen in Table 1 , Table 2, and Table 3.

Table 1. The cell degeneration of lungs histopathologic score [22].

\begin{tabular}{c|c|c} 
Score & Changing level & Percentage of damage \\
\hline $\mathbf{0}$ & none & $0 \%$ \\
\hline $\mathbf{1}$ & Cells degeneration reach $1 / 4$ of total observed & $25 \%$ \\
\hline $\mathbf{2}$ & Cells degeneration reach $1 / 2$ of total observed & $50 \%$ \\
\hline $\mathbf{3}$ & Cells degeneration reach $3 / 4$ of total observed & $75 \%$ \\
\hline $\mathbf{4}$ & Complete cells degeneration & $100 \%$
\end{tabular}

Table 2. The cell necrosis of lungs histopathologic score [22].

\begin{tabular}{c|c|c} 
Score & Changing level & Percentage of damage \\
\hline $\mathbf{0}$ & none & $0 \%$ \\
\hline $\mathbf{1}$ & Necrosis reach $1 / 4$ of total observed & $25 \%$ \\
\hline $\mathbf{2}$ & Necrosis reach $1 / 2$ of total observed & $50 \%$ \\
\hline $\mathbf{3}$ & Necrosis reach $3 / 4$ of total observed & $75 \%$ \\
\hline $\mathbf{4}$ & Complete necrosis & $100 \%$
\end{tabular}

Table 3. The pleural thickening of lungs histopathologic score [22]

\begin{tabular}{c|c|c} 
Score & Changing level & Percentage of damage \\
\hline $\mathbf{0}$ & none & $0 \%$ \\
\hline $\mathbf{1}$ & Mucosa thickening reach $1 / 4$ of total observed & $25 \%$ \\
\hline $\mathbf{2}$ & Mucosa thickening reach $1 / 2$ of total observed & $50 \%$ \\
\hline $\mathbf{3}$ & Mucosa thickening reach $3 / 4$ of total observed & $75 \%$ \\
\hline $\mathbf{4}$ & Complete mucosa thickening & $100 \%$
\end{tabular}




\section{Results and Discussion}

The results study of leukocyte differential count using blood smear methods could be seen in table 4, and statistical analysis using the Anova One Way test and the Kruskal Wallis test of each variable could be seen in table 5. The results of histopathologic findings in lungs can be seen in table 6 .

Table 4. The differential count of leukocytes.

\begin{tabular}{l|c|c|c|c|c|c|c} 
Group & \multirow{2}{*}{$\boldsymbol{N}$} & \multicolumn{6}{|c}{ Leukocyte Differential (Mean \pm Standard Error) } \\
\cline { 3 - 8 } & & Basophils (\%) & $\begin{array}{c}\text { Eosinophils } \\
(\boldsymbol{\%})\end{array}$ & $\begin{array}{c}\text { Neutrophils } \\
\text { Stab (\%) }\end{array}$ & $\begin{array}{c}\text { Neutrophils } \\
\text { Segment (\%) }\end{array}$ & $\begin{array}{c}\text { Lymphocyte } \\
(\boldsymbol{\%})\end{array}$ & $\begin{array}{c}\text { Monocyte } \\
(\boldsymbol{\%})\end{array}$ \\
\hline P1 & 10 & $40.00 \pm 10.11$ & $2.00 \pm 1.33$ & $9.00 \pm 2.33$ & $4.00 \pm 2.21$ & $71.00 \pm 14.33$ & $46.00 \pm 7.77$ \\
\hline P2 & 10 & $32.00 \pm 8.41$ & $1.00 \pm 1.00$ & $3.00 \pm 1.53$ & $5.00 \pm 3.41$ & $76.00 \pm 15.07$ & $42.00 \pm 5.73$ \\
\hline P3 & 10 & $28.00 \pm 3.89$ & $4.00 \pm 2.21$ & $10.00 \pm 3.94$ & $6.00 \pm 2.21$ & $59.00 \pm 7.06$ & $53.00 \pm 5.78$
\end{tabular}

Table 5. Statistical difference test of leukocyte profile.

\begin{tabular}{l|c} 
Leukocyte Profile & $\boldsymbol{P}$-value \\
\hline Basophils & $0.558^{\mathrm{a}}$ \\
\hline Eosinophils & $0.504^{\mathrm{b}}$ \\
\hline Neutrophils Stab & $0.136^{\mathrm{b}}$ \\
\hline Neutrophils Segment & $0.578^{\mathrm{b}}$ \\
\hline Lymphocyte & $0.627^{\mathrm{a}}$ \\
\hline Monocyte & $0.490^{\mathrm{a}}$ \\
\multicolumn{2}{|c}{ Anova One Way test, significant P-value $<0.05$} \\
\multicolumn{2}{l}{ Kruskal Wallis test, significant P-value $<0.05$}
\end{tabular}

Table 6. The lungs' cell damage due to insect repellent exposure.

\begin{tabular}{l|c|c|c|c|c}
\multirow{2}{*}{$\begin{array}{c}\text { Mosquito Repellent } \\
\text { Exposure }\end{array}$} & \multirow{2}{*}{} & \multicolumn{3}{|c|}{ The Lungs Cell Damage } & \multirow{2}{*}{$\begin{array}{c}\text { Percentage of Lungs Cell } \\
\text { Damage }\end{array}$} \\
\cline { 3 - 5 } & & Degeneration & Necrosis & Pleural Thickening & \\
\hline Coils (P1) & 10 & 0 & 0 & 0 & None \\
\hline Liquid electric (P2) & 10 & 0 & 0 & 0 & None \\
\hline Mat Electric (P3) & 10 & 0 & 0.3 & 1.2 & $\begin{array}{l}\text { Necrosis } 7.5 \% \\
\text { Pleural thickening } 30 \% .\end{array}$
\end{tabular}

Based on statistical difference test showed on the differential count of leukocyte explained the kind of insect repellent exposure did not affect leukocyte profile in the blood due to P-Value > 0.05. Meanwhile, the lungs histopathologic results showed that exposure to mosquito repellent coils and liquid electricity for 8 hours in a day and 20 days were safe to use daily because they had no effect on degeneration cell, necrosis cell, and pleural thickening. Whereas mat electric exposure, which had dimefluthrin content higher than others, could be contributed in necrosis cell about $7.5 \%$ and pleural thickening about $30 \%$. The presence of necrosis and pleural thickening on P3 can be seen in figure 1. The black arrow in figure 1 (a) showed necrosis cells, and the black arrow in figure 1(b) showed pleural thickening.

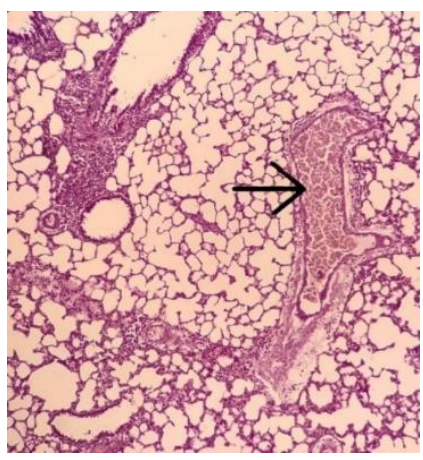

(a)

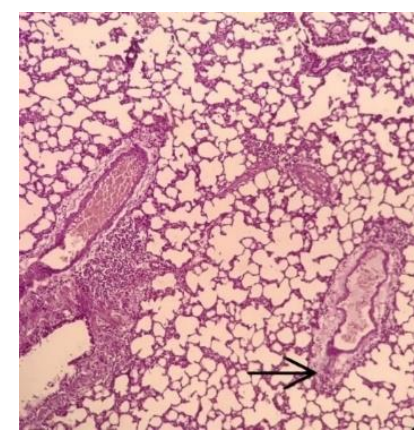

(b)

Figure 1. Histopathologic findings in lungs of P3 intervention: a) necrosis, b) pleural thickening. 
The mosquito repellent smoke could cause high air pollution, which is inhaled by humans and animals could increase free radicals in the body [8]. Free radicals with high concentrations contribute to cell damage, inhibit the normal production of DNA, promote damage to cell membrane lipids, and cause cell death [3]. The number of free radicals increases along with the decrease in antioxidant production in the body and causes oxidative stress [15], resulting in various degenerative diseases, including Alzheimer's, cancer, and heart disease. Therefore, optimal antioxidants could inhibit the occurrence of oxidative stress in the body $[15,23]$.

The lungs have direct contact with the outside air; therefore, they are very vulnerable to exposure to hazardous materials such as toxic gases, pathogenic microorganisms, and particles of dust. The lungs have defense mechanisms to protect themselves from outsider material. The particles measuring $>10 \mathrm{~m}$ could be bound in the nasal cavity, while those measuring 5-10 m could be filtered in the bronchial branches, but those measuring $<3 \mathrm{~m}$ could entrance in the alveoli [24].

Free radicals in insect repellent exposure could interact with leukocytes in the blood through the respiratory system. Based on the study, results showed that the higher eosinophil, neutrophil stab, neutrophil segment, and monocyte counts were P3. The higher basophil count was $\mathrm{P} 1$, and the higher of lymphocyte was P2. However, the statistical analysis explained there were no significant differences in each variable. Therefore, dimefluthrin compounds in insect repellent might not have an effect on leukocytes in the blood.

The study was observed there was a presence of necrosis cells and pleural thickening on the P3 group. Meanwhile, in P1 \& P2, groups were absent. Insect repellent mat electric exposure could be caused by several chemical substances, particularly dimeflutrin with a high concentration. The dimeflutrin content in mat electric is higher than liquid electric and coils repellent. In addition, continuous exposure to insect repellent smoke can cause degenerated cells to become necrotic cells [25]. Mucous thickening in this study could be observed in the P3 group that was exposed to the smoke of electric mosquito coils with high concentrations of Dimefluthrin. Pleural thickening was observed in $30 \%$ of lungs, particularly those with the lumen that could be due to mucosal hyperplasia. Necrosis is the death of cells or tissues caused by an irreversible degeneration process. The main characteristics of cells or tissues undergoing necrosis, namely pyknosis, are characterized by dark nuclei (hyperchromatic) and shrinking [26]. Karyorrhexis is characterized by a cracked nucleus, and karyolysis is characterized by missing or only hollow nuclei and missing chromatin [26]. Thickening is the damage and proliferation of scar tissue in the lung parenchyma tissue, which causes the lung parenchyma tissue to become thick and stiff [27]. Alveolar wall thickening is characterized by alveolar diameter marking, Bronchus Associated Lymphoid Tissue (BALT) hyperplasia, and infiltration of cells including (macrophages) [24].

A comparative study of various insect repellents on the liver, brain, kidneys, lungs, and heart of Swiss albino rats exposed 3 hours a day for 20 days showed a significant toxicological effect [3]. Lung damage was almost affected by various insect repellents. Inhaled mosquito vapor in the body contributes to free radicals that cause lung injury and DNA damage that can trigger necrosis, apoptosis, cell degeneration, cell thickening, inflammation, and carcinogenesis [3,22]. Necrosis is acute and irreversible cell damage so that cells cannot continue their metabolic processes because there are active or toxic substances that enter the bloodstream to the organs [26]. In the lungs, cell necrosis could be caused by the direct influence of toxic agents, including chemicals, toxic bacteria, and caused by a lack of factors 
needed by cells such as oxygen and nutrients [25]. Besides, other factors that could affect the onset of disease or disorders in the respiratory tract include particles, content concentration, solubility, chemical properties, and individual factors, including lung defense, duration of exposure, and exposure from other sources [28-35].

Exposure to mosquito coil smoke stimulates excrete fluid or mucus in the lungs. However, in the P1 and P2 groups, no mucosal thickening was seen; this could be due to the low content of dimefluthrin and the lack of duration of exposure to electric mosquito repellent liquid and mosquito coils [20].

Based on the results, the higher the exposure to dimeflutrin, the higher the damage to lung tissue, especially the thickening and necrosis of lung tissue. However, further research is needed to obtain more comprehensive research results.

\section{Conclusions}

The usage of mosquito coils and electric liquid mosquito repellent for 8 hours in 20 days had no significant effect on leukocyte profile in blood and absent lungs damage. Mosquito coils exposure increased the lymphocytes' count, and the electric liquid-repellent increased the basophils' count. However, the electric mat insect repellent exposure with the higher dimefluthrin contents in repellent is still not recommended for the use, which was contributed in a higher number of eosinophils; neutrophils stab, neutrophils segment, and monocytes descriptively in the blood. Besides, histopathology findings in the lungs showed that the electric mat exposure contributed to cells degeneration $7.5 \%$ and pleural thickening $30 \%$. The duration of exposure to insect repellent containing dimefluthrin in rats can be extended to determine the specific effect of the dimefluthrin content and the duration of exposure to insect repellent through Red Blood Cells (RBC), White Blood Cells (WBC), and lung damage.

\section{Funding}

This research was funded by Lembaga Penelitian dan Pengabdian Masyarakat, Universitas Nahdlatul Ulama Surabaya, grant No. 161.3/UNUSA/Adm-LPPM/III/2021.

\section{Acknowledgments}

Thank to Lembaga Penelitian dan Pengabdian Masyarakat, Universitas Nahdlatul Ulama Surabaya to support the study through research grants No. 161.3/UNUSA/AdmLPPM/III/2021.

\section{Conflicts of Interest}

The authors declare no conflict of interest.

\section{References}

1. Kirik, H.; Burtin, V.; Tummeleht, L.; Kurina, O. Friends in all the green spaces: Weather dependent changes in urban mosquito (diptera: Culicidae) abundance and diversity. Insects 2021, 12, 1-18, https://doi.org/10.3390/insects12040352.

2. Roy, D.N.; Goswami, R.; Pal, A. The insect repellents: A silent environmental chemical toxicant to the health. Environ Toxicol Pharmacol 2017, 50, 91-102, https://doi.org/10.1016/j.etap.2017.01.019.

3. Naz, M.; Rehman, N.; Ansari M.N.; Kamal, M.; Ganaie, M.A.; Awaad, A.S.; Alqasoumi, S.I. Comparative study of subchronic toxicities of mosquito repellents (coils, mats and liquids) on vital organs in Swiss albino mice. Saudi Pharm J 2019, 27, 348-353, https://doi.org/10.1016/j.jsps.2018.12.002.

4. Syafiuddin, A.; Salmiati, S.; Salim, M.R.; Kueh, A.B.H.; Hadibarata, T.; Nur, H. A Review of Silver https://biointerfaceresearch.com/ 
Nanoparticles: Research Trends, Global Consumption, Synthesis, Properties, and Future Challenges. J Chinese Chem Soc 2017, 64, 732-756, https://doi.org/10.1002/jccs.201700067.

5. Syafiuddin, A.; Salmiati, S.; Hadibarata, T.; Kueh, A.B.H.; Salim, M.R.; Zaini, M.A.A. Silver Nanoparticles in the Water Environment in Malaysia: Inspection, characterization, removal, modeling, and future perspective. Sci Rep 2018, 8, https://doi.org/10.1038/s41598-018-19375-1.

6. Al-Damegh, M.A. Toxicological impact of inhaled electric mosquito-repellent liquid on the rat: a hematological, cytokine indications, oxidative stress and tumor markers. Inhal Toxicol 2013, 25, 292-297, https://doi.org/10.3109/08958378.2013.781251.

7. Sinha. C.; Agrawal, A.; Islam, F.; Seth, K.; Chaturvedi, R.; Shukla, S.; Seth, P. Mosquito repellent (pyrethroid-based) induced dysfunction of blood-brain barrier permeability in developing brain. Int J Dev Neurosci 2004, 22, 31-37, https://doi.org/10.1016/j.ijdevneu.2003.10.005.

8. Juswono, U.P.; Wardoyo, A.Y.P.; Widodo, C.S.; Noor, J.A.E.; Santoso, D.R. The impact of exposure to aerosol mosquitoes repellent related to free radicals on the organs of male mice. Int J GEOMATE 2020, 18, 78-83, https://doi.org/10.21660/2020.67.5770.

9. Elsayed, G.A.; Hassabo, A.G. Insect repellent of cellulosic fabrics (A Review). Letters in Applied NanoBioscience 2022, 11, 3181-3190.

10. Tavares, M.; da Silva M.R.M.; de Oliveira de Siqueira, L.B.; Rodrigues, R.A.S.; Bodjolle-d'Almeida, L.; Dos Santos, E.P.; Ricci-Júnior, E. Trends in insect repellent formulations: A review. Int J Pharm 2018, 539, 190209, https://doi.org/10.1016/j.ijpharm.2018.01.046.

11. Deletre, E.; Martin, T.; Duménil, C.; Chandre, F. Insecticide resistance modifies mosquito response to DEET and natural repellents. Parasit Vectors 2019, 12, https://doi.org/10.1186/s13071-019-3343-9.

12. Yang, X.; Zhou, Y.; Sun, Y.; Liu, J.; Jiang, D. Multiple insecticide resistance and associated mechanisms to volatile pyrethroid in an Aedes albopictus population collected in southern China. Pestic Biochem Physiol 2021, 174, https://doi.org/10.1016/j.pestbp.2021.104823.

13. Yuan, L.; Yang, X.; Yu, X.; Wu, Y.; Jiang, D. Resistance to insecticides and synergistic and antagonistic effects of essential oils on dimefluthrin toxicity in a field population of Culex quinquefasciatus Say. Ecotoxicol Environ Saf 2019, 169, 928-936, https://doi.org/10.1016/j.ecoenv.2018.11.115.

14. Kumar,V.; Sankar, J. Liquid Mosquito Repellents - Keep Them Away from Toddlers. Indian J Pediatr 2020, 87, https://doi.org/10.1007/s12098-019-03132-x.

15. Anitha. M.; Anitha, R.; Vijayaraghavan, R.; Senthil Kumar, S.; Ezhilarasan, D. Oxidative stress and neuromodulatory effects of deltamethrin and its combination with insect repellents in rats. Environ Toxicol 2019, 34, 753-759, https://doi.org/10.1002/tox.22741.

16. Islam, J.; Zaman, K.; Chakrabarti, S.; Chattopadhyay, P. Exploration of toxicological impacts following acute and sub-chronic exposure to ethyl anthranilate-loaded mosquito repellent patch. Regul Toxicol Pharmacol 2018, 97, 209-224, https://doi.org/10.1016/j.yrtph.2018.06.020.

17. Abdulaziz, A.; Avwioro, O.G.; Abdul Rasheed, M.O.; Abubakar, M.S.; Abubakar, U.; Abubakar, S.D.; Shagari, M.B. D-trans-allethrins in Some Selected Mosquito Coil Repellents Causes Histological Inflammation in Trachea of Experimental Animals. Int $J$ Pathog Res 2020, 3, 1-7, https://doi.org/10.9734/ijpr/2019/v3i330096.

18. Armalina, D.; Witjahjo, B.; Susilaningsih, N. Histopathological changes in liver, kidney and teratogenic effects of mice on exposure to mosquito repellent. J Kedokt dan Kesehat Indones 2021, 12, 11-18, https://doi.org/10.20885/JKKI.Vol12.Iss1.art4.

19. Juswono, U.P. The Effects of Transfluthrin As the Active Substance of One Push Aerosol Repellent on Organs Damage of Mice (Mus Musculus) (Case Study of Lung, Liver, Bloods, and Kidney). Int J GEOMATE 2019, 16, 113-118, https://doi.org/10.21660/2019.55.8260.

20. Monica, M.; Adi, A.A.A.M.; Winaya, I.B.O. Histopatologycal Bronkiolus and Blood Vessel of Mice Lung Post Exposure of Electric Cigarette Smoke. Bul Vet Udayana 2019, 11, 157-165, https://doi.org/10.24843/bulvet.2019.v11.i02.p08.

21. Morton, J.; Snider, T. Guidelines for collection and processing of lungs from aged mice for histological studies. Pathobiol Aging Age-related Dis 2017, 7, https://doi.org/10.1080/20010001.2017.1313676.

22. Gibson-Corley, K.N.; Olivier, A.K.; Meyerholz, D.K. Principles for histopathologic scoring. Vet Pathol 2008, 23, 1-7, https://doi.org/10.1177\%2F0300985813485099.

23. Tan, B.L.; Norhaizan, M.E.; Liew, W.P.P.; Rahman, H.S. Antioxidant and oxidative stress: A mutual interplay in age-related diseases. Front Pharmacol 2018, 9, 1-28, https://doi.org/10.3389/fphar.2018.01162.

24. Herdiani, N.; Putri, E.B.P. Gambaran Histopatologi Paru Tikus Wistar Setelah Diberi Paparan Asap Rokok. Med Heal Sci J. 2018, 2, https://doi.org/10.33086/mhsj.v2i2.583.

25. Waskitha, M.P.; Setiasih, N.L.E.; Samsuri, S.; Berata, I.K. Histopathology Lung of White Female Rats due to Supplementation of Tape Yeast in Rat Feed. Indones Med Veterinus 2020, 9, 662-671, https://doi.org/10.19087/imv.2020.9.5.662.

26. Pratama, A.P.C.; Berata, I.K.; Samsuri, S.; Merdana, I.M. The Effect of Vitamin E and Dexametasone to Histopatological of White Male Rats Heart. Bul Vet Udayana 2018, 10, https://doi.org/10.24843/bulvet.2018.v10.i02.p07.

27. Moore, B.; Lawson, W.E.; Oury, T.D.; Sisson, T.H.; Raghavendran,K.; Hogaboam, C.M. Animal models of 
fibrotic lung disease. Am J Respir Cell Mol Biol 2013, 49, 167-179, https://doi.org/10.1165/rcmb.20130094tr.

28. Gorguner, M.; Akgun, M. Acute inhalation injury. Eurasian J Med 2010, 42, 28-35.

29. Zajac, D. Inhalations with thermal waters in respiratory diseases. J. Ethnopharmacol. 2021, 281, https://doi.org/10.1016/j.jep.2021.114505.

30. Hussain, M.S.; Sharma, P.; Dhanjal, D.S.; Khurana, N.; Vyas, M.; Sharma, N.; Mehta, M.; Tambuwala, M.M.; Satija, S.; Sohal, S.S.; Oliver, B.G.G.; Sharma, H.S., Nanotechnology based advanced therapeutic strategies for targeting interleukins in chronic respiratory diseases. Chem. Biol. Interact. 2021, 348, https://doi.org/10.1016/j.cbi.2021.109637.

31. Nozza, E.; Valentini, S.; Melzi, G.; Vecchi, R.; Corsini, E. Advances on the immunotoxicity of outdoor particulate matter: A focus on physical and chemical properties and respiratory defence mechanisms. Sci. Total Environ. 2021, 780, https://doi.org/10.1016/j.scitotenv.2021.146391.

32. Gao, D.; Ripley, S.; Weichenthal, S.; Godri Pollitt, K.J. Ambient particulate matter oxidative potential: Chemical determinants, associated health effects, and strategies for risk management. Free Radic. Biol. Med. 2020, 151, 7-25, https://doi.org/10.1016/j.freeradbiomed.2020.04.028.

33. Misiukiewicz-Stepien, P.; Paplinska-Goryca, M., Biological effect of PM10 on airway epithelium-focus on obstructive lung diseases. Clin. Immunol. 2021, 227, https://doi.org/10.1016/j.clim.2021.108754.

34. Vo, T.T.T.; Wu, C.-Z.; Lee, I.T. Potential effects of noxious chemical-containing fine particulate matter on oral health through reactive oxygen species-mediated oxidative stress: Promising clues. Biochem. Pharmacol. 2020, 182, https://doi.org/10.1016/j.bcp.2020.114286.

35. Montefusco-Pereira, C.V.; Carvalho-Wodarz, C.d.S.; Seeger, J.; Kloft, C.; Michelet, R.; Lehr, C.-M., Decoding (patho-)physiology of the lung by advanced in vitro models for developing novel anti-infectives therapies. Drug Discov. Today 2021, 26, 148-163, https://doi.org/10.1016/j.drudis.2020.10.016. 